\title{
Road Safety Assessment from Rustaq to Ibri
}

\author{
Yasmine Abdullah Khalfan \\ Alzeedi \\ Adams Joe
}

This paper will discuss the road safety assessment methods which are the road safety check to determine the road safety risks. safety professional considers road and traffic characteristics and crashes history The area of study is the Rustaq -Ibri road. The road was built in 2006, it is connected between Muscat and the governorates of Al-Dhahirah and South Batinah. The length is about $80 \mathrm{Km}$, and the speed limit is between 60 and $80 \mathrm{Km} / \mathrm{h}$. By using the road safety check method to identify the problems which can happen due to the geometric design of the road, and the causes of car accidents on this road. This report will mention the effect of the geometric design of road on the number of car accidents, the causes of car accidents in this road, and provide suitable solutions to increase the safety on Rustaq-Ibri road.

\section{INTRODUCTION}

The road safety assessment in Oman's roads specifically in Rustaq - Ibri road which connects Rustaq and Ibri. It is around 80 kilometers long across the mountains and mountain slopes and the journey takes about an hour to cross this distance. Users of this route may face many difficulties that can put them at risk and obstruct traffic such as, sharp curves, the fallen stones on the road, Wadi channels, the sudden change of elevation, no clear lines or marking which leads to straight off the road specifically at night drive as well as the traffic signals and signboards, the wrong place of junction and humps,...etc. The aim of this study to identify the problems in Rustaq - Ibri road and solve these problems in the right way to feel the users more comfortable and to minimize the number of accidents in this road and to explore the effect of the geometric design of Rustaq - Ibri road on the number of a car accident. The expected results from this research are to improve the safety of Rustaq - Ibri road, Also, minimize the number of car accidents in Rustaq - Ibri road.

\section{LITERATURE REVIEW}

\section{Geometric design of roads}

The Road Safety Assessments (RSAs)are a proactive approach to improving road safety. Use to assessment of the safety performance of an existing or planned road segment or an intersection. Used RSA in all step of construction including: planning, traffic control planning, final design, preopening, construction and on existing roads. The RSAs helps to decreases the number of severity crashes, reduce the cost and helps promote awareness (Azmag, 2018).

\section{Factor affecting the geometric design of road}

The most important factor affecting the geometric design of the highway is the design speed. According to AASHTO, should select the speed of the road because it has a major influence on traffic operations. AASHTO states that the drivers should satisfied with the level of services of the road throughout its life span (Bright hub engineering, 2018).

Determine the speed of road depend on the weather conditions, the person driving, the vehicle type and the topography. Design speed is the most important factor in the geometric design of 
highways, to facilitate safety travelling of the vehicles. The design speeds are different for every road by standard (The constructor ,2017).

\section{Car accident and injuries rates in Oman}

In 2012, the number of car accidents was sharply increased as it has reached approximately 8729 accidents, from 2014 to 2016 the number of car accidents has fallen. The number of car accidents has steadily decreased to almost 1014 accidents in 2018.

\section{Causes of accident in Oman}

In 2016 the total car accidents was 4721 accidents, where the speed the cause of 2499 accidents. Then, bad behavior is the second causes of accident in Oman, where resulted in 705 accidents , 55 deaths and 412 injuries. In addition, Negligence le to 672 accidents, 103 deaths and 296 injuries (Times of Oman, 2017).

\section{Safety measures of roads}

There are four ways to reduce the numbers of deaths and injuries from the car accidents (Elvik,Vaa and Hoye...et al. ,2009):

1. By reducing the amount of travel, that is mean reduce the numbers of kilometers travel.

2. By choose the transport which have s lower level of risk

3. By reducing the accident rate for a given amount of travel

4. By reducing the accident severity, that is, by protecting people better from injury

\section{RESEARCH METHODOLOGY}

To achieve the purpose of this project was used Quantitative research and Qualitative research which includes interviews, surveys, real data, and previous information.

\section{Selecting study area}

The area of study is on South Batina, it is Rustaq. This is called Rustaq - Ibri road this area has the medium population and the users of the road from different areas. The reason for selection of this road is, it act as the majortransportation link between Muscat and Al-Dhahirah and South Batina, this is a very busy road and we can see more people using this road especially during weekend and occasions and the accidents rates are more.

\section{Data analysis}

Reviewed the analysis of the questionnaire by the PSPP software that used for this purpose to find the result.

\section{RESULT AND DISCUSSION}

\section{The effect of geometric design of Rustaq- Ibri road on the number of car accidents}

Rustaq -Ibri is crossing a huge mountains with a lot of ben, this road was constructed since more than 10 years it crosses many valleys and a lot of sharp curves. This road is a single road total wide $7.3 \mathrm{~m}$ and two-lane each one $3.65 \mathrm{~m}$ wide and hard strip in two sides $1 \mathrm{~m}$ (Rogers 2008). 


\section{Journal of Student Research}

Fourth Middle East College Student Research Conference, Muscat, Sultanate of Oman

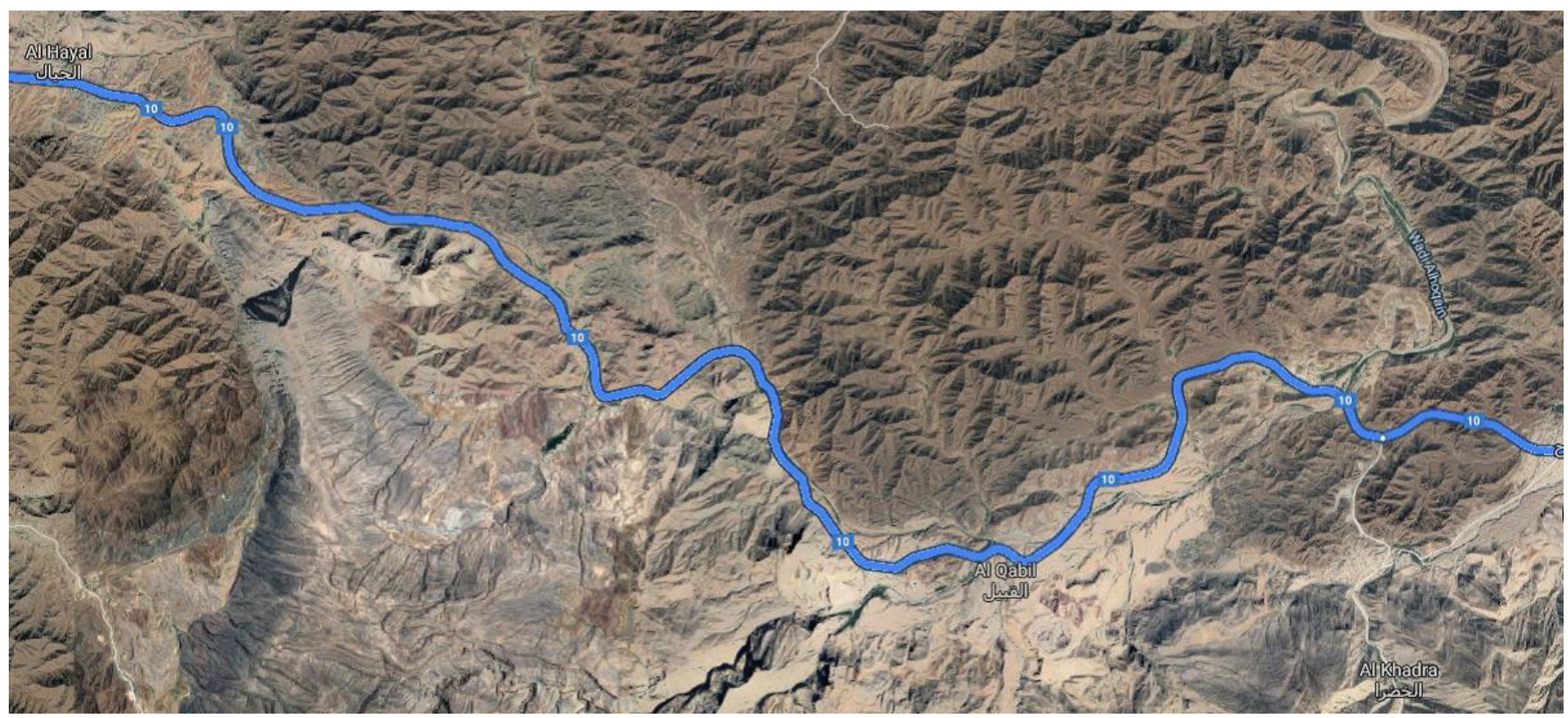

Figure 1. The huge mountains and curves in Rustaq-Ibri road

\section{The Geometric design of road and the car accidents}

\begin{tabular}{|c|c|c|c|c|c|}
\hline Value Label & Value & Frequency & Percent & Valid Percent & Cum Percent \\
\hline & no & 15 & 25.00 & 25.00 & 25.00 \\
\hline & yes & 45 & 75.00 & 75.00 & 100.00 \\
\hline & Total & 60 & 100.0 & 100.0 & \\
\hline
\end{tabular}

\section{geometric_design_of_the_road}

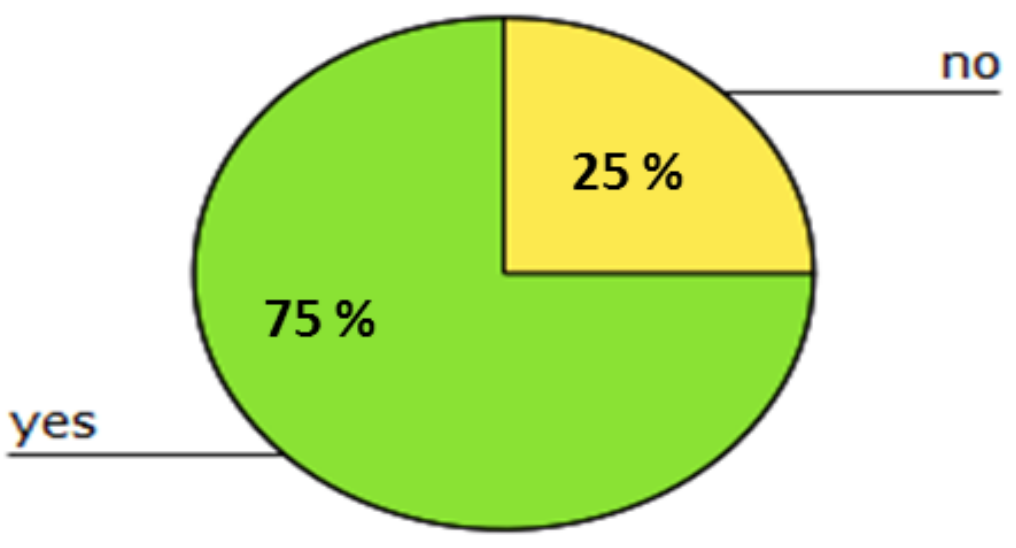

Figure 2. The geometric design of road 
The diagram above illustrates that if the geometric design of Rustaq-Ibri road is one of the causes to increase the car accidents on this road. Around $75 \%$ of the users agrees that the geometric design is the one of the causes of increasing the car accidents due to the slopes and curves which make difficulties to see the road and the traffic signs clearly where $25 \%$ of them responded that the geometric design does not affect the number of car accidents. We concluded that the road should be designed to be more comfortable for users as well as this road needs to enhance safety by amending the geometric design of the road.

\section{The number of car accidents in Rustaq-Ibri road}

The data collected is according to Royal Oman Police (ROP) from the interview with the department of statistics in general directorate of traffic.

\begin{tabular}{|c|c|c|c|}
\hline Year & Accidents & Fatalities & Injuries \\
\hline $\mathbf{2 0 1 4}$ & 64 & 12 & 85 \\
\hline $\mathbf{2 0 1 5}$ & 70 & 17 & 93 \\
\hline $\mathbf{2 0 1 6}$ & 68 & 9 & 78 \\
\hline $\mathbf{2 0 1 7}$ & 73 & 15 & 81 \\
\hline $\mathbf{2 0 1 8}$ & 76 & 18 & 90 \\
\hline
\end{tabular}

Figure 3. Number of car accidents in Rustaq-Ibri road (ROP)

\section{The causes of car accidents in Rustaq-Ibri road}

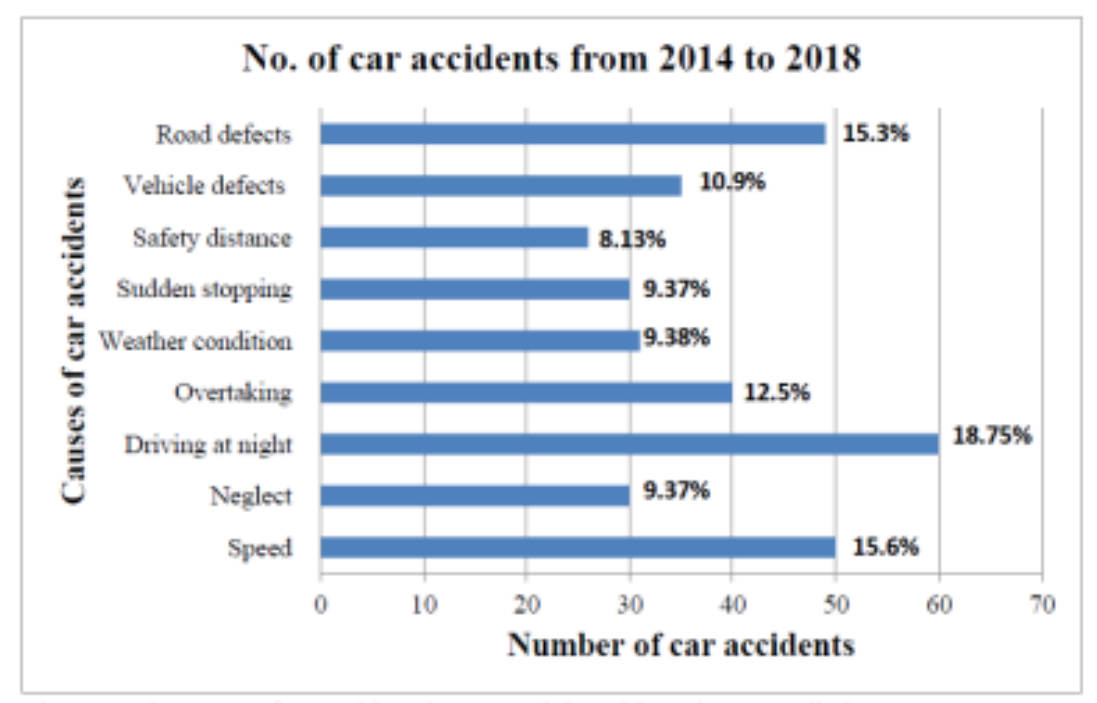

Figure 4. The causes of car accidents in Rustaq-Ibri road (Royal Oman Police)

From the above chart, the data on causes of car accidents which according to the Royal Oman Police. Driving at night is the first cause of accidents in the last 5 years. The second cause of accidents in this road as shown in the above chart is the speed, the speed limits are 60 to $80 \mathrm{Km} / \mathrm{h}$. The third cause of accidents is the road defects, which is related to the geometric design of the road. The problems in the road such as there are no street lights along the road, the traffic signs are not clear and the slopes and curves. Finally, from the survey for the users of the road and the 
interview with the department of statistics in general directorate of traffic in Royal Oman Police found that the three major causes of car accidents on Rustaq-Ibri road are driving at night, speed and road defects.

\section{Provide suitable solutions to increase the safety on Rustaq-Ibri road}

1. The Rustaq-Ibri road surface marking is not clear for the drivers. The road surface marking is removed due to the many factors such as water, wind or car wheels. The solution for this problem is to repaint the road surface marking, add the cat's eyes road and add street lights along this road.

2. The rock fall protection is important to apply it on the mountain especially where the road or the residential area. In Rustaq-Ibri road there is no rock fall protection from the mountain along the road, increases the rocks fall on rainy days or due to the wind. So, Can use drapery system with hexagonal mesh or rock fall protection embankments.

3. Should add traffic signs more attractive to reduce car accidents.

\section{CONCLUSIONS}

To our knowledge, no similar studies have been carried out on road safety assessment in RustaqIbri road. This research, conducted in Rustaq-Ibri road, the number of car accidents is increased from 2014 to 2018 by $8.5 \%$. The causes of car accidents in the last five year are driving at night, speed, and road defects. The geometric design effects to the number of car accidents in this road. Whereas the number of car accidents due to the road defects is high also road defects is one of the causes of car accidents in Rustaq-Ibri road. From the result and discussion, found the problems in this road there are no proper street lights, the width of the road is insufficient for the fast moving vehicles, a lot of series curves and intersections, traffic signs is not clearly visible during night time and there is no proper rock fall protection. Therefore, to increase the safety in this road will increased the width of the road or add more one lane, add more attractive traffic signs, add lights along the road, apply the rock fall protection along the Rustaq-Ibri road can use drapery system with hexagonal mesh or rock fall protection embankments. Also, repaint the road surface marking and add the cat's eyes road.

\section{ACKNOWLEDGEMENT}

I thank the Almighty God for his kindness and love he has bestowed on me to enable this thesis and manage to complete it.

We would like to thank our supervisor Mr. Adams Joe for his encouragement, endless support, guidance, and all his valuable advices throughout the process of completing this project as well as I thank all the members of the Engineering department for all their generous assistance over the year. Additionally, I would thank my friends and family who contributed to complete this work successfully.

\section{REFERENCES}

1. Abu Abdo, A. (2017)' SENSITIVITY ANALYSIS OF TRAFFIC ACCIDENTS CAUSES IN SULTANATE OF OMAN'. ARPN Journal of Engineering and Applied Sciences 12, (11 ) 35543560

2. Azmag (2019) Introduction to Road Safety Assessments.[Online] Available from<http://azma g.gov/Portals/0/Documents/TSC_2010-12-03_Introduction-to-Road-SafetyAssessments.pdf?ver $=2017-04-06-112044-7 \overline{30}>[12$ November 2019]

3. Blaeij,A. , Florax,R. , Rietveld,P. , Verhoef,E. (2000) 'The Value of Statistical Life in Road Safety: A Meta-analysis' Journal of Accident Analysis and Prevention 35(6): 973-986 


\section{Journal of Student Research}

Fourth Middle East College Student Research Conference, Muscat, Sultanate of Oman

4. Elvik,R. ,Vaa,T. ,Hoye,A. ,Sorensen,M. (2009) The Handbook of Road Safety Measures: Second Edition. Emerald group publishing limited: UK

5. Inaam Akhtar (2016)' Research in Social Science: Interdisciplinary Perspectives ,Chapter: Research Design' Research in Social Science Interdisciplinary Perspectives (Edition: 1st) 1-84

6. Islam, M. and Kanitpong, K. (2008) 'IDENTIFICATION OF FACTORS IN ROAD ACCIDENTS THROUGH IN-DEPTH ACCIDENT ANALYSIS'. Journal of IATSS RESEARCH 32 (2), 58-67

7. Marta, D., Smart, W., Dr Saffron, D., Hamilton, B., Bhatnagar, Y.(2011) 'Road safety assessment methods: deciding which one to use' Australasian Road Safety Research, Policing and Education Conference. [Online] 2 (1), 1-8 Available from< http://casr.adelaide.edu.au/rsr/RSR2011/1BPaper\%20009\%20Marta.pdf> [11 November 2019]

8. Rogers,M. (2008). Highway Engineering. Library of Congress Cataloging: Ireland.

9. Times of Oman (2018) 'Road accidents down by nearly 40 per cent in 2018' (Online) Available from < https://timesofoman.com/article/137629> [6 November 2019]

10. The constructor (2019) What is Geometric Design of Highways and Factors Affecting it? [Online] Available from <https://theconstructor.org/transportation/geometric-design-ofhighways-factors/20897/>[ 1 November 2019] 